\title{
Pengelolaan Sumber Daya Genetik Kambing sebagai Potensi Biologik dan Nilai Ekonomi
}

\author{
Goat Genetic Resources Management as Biological Potential and Economic Values
}

\author{
S. Rusdiana* dan U. Adiati \\ Balai Penelitian Ternak Ciawi-Bogor, PO.Box.221 Bogor Jawa Barat. \\ * Corresponding e-mail: s.rusdiana20@gmail.com
}

\begin{abstract}
The research objective was to determine the management of goat genetic resources as a biological potential and economic value. The research was carried out in the experimental cage Ciawi-Bogor 2018. The study used $35 \mathrm{PE}$ goats, 30 females and 5 males, AN 35 goats, 30 females and 5 males. The data analysis methods were carried out by descriptive, quantitative and economic analysis. The results showed that the average mating body weight of female goats PE was $40.71 \pm 9.94 \mathrm{~kg}$ and AN female goat was $43.10 \pm 12.13 \mathrm{~kg}$. The average body weight of female PE goats after giving birth was $41.84 \pm 9.18 \mathrm{~kg}$ and the mean body weight of female AN goats after giving birth was $42.81 \pm 9.42 \mathrm{~kg}$. The production of male goats with PE was $26.48 \%$. Meanwhile, the female goats with PE were $22.22 \%$, AN $28.79 \%$ male goats, while AN 24.24\% female goats. Profits from the PE goat business IDR 17.730.000/year R/C 1.52. The profit from the AN goat business is IDR 16.126.670/year R/C 1.44. PE and AN goats can be kept for $>5$ years, $\mathrm{PE}$ and $\mathrm{AN}$ goats can produce milk and meat and can give birth twice in 1.5 years, and economically the goat business is feasible to run.
\end{abstract}

Key words: management of goat genetic resources, economic value

\begin{abstract}
ABSTRAK
Tujuan penelitian untuk mengetahui pengelolaan sumber daya genetik kambing sebagai potensi biologik dan nilai ekonomi. Penelitian dilakukan di kandang percobaan Ciawi-Bogor 2018. Penelitian menggunakan kambing PE 35 ekor, betina 30 ekor dan jantan 5 ekor, Kambing AN 35 ekor, betina 30 ekor dan jantan 5 ekor. Metode analisis data dilakukan secara deskriprif, kuantitatif dan analisis ekonomi. Hasil penelitian menunjukkan, rata-rata bobot

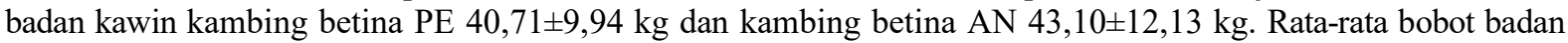
kambing betina PE setelah beranak 41,84 $\pm 9,18 \mathrm{~kg}$ dan rata-rata bobot badan kambing betina AN setelah beranak $42,81 \pm 9,42 \mathrm{~kg}$. Produksi anak kambing jantan PE 26,48\%. Sedangkan anak kambing betina PE 22,22\%. Anak kambing jantan AN 28,79\%, sedangkan anak kambing betina AN 24,24\%. Keuntungan dari usaha kambing PE Rp.17.730.000/tahun R/C 1,52. Keuntungan dari usaha kambing AN Rp.16.126.670/tahun R/C 1,44. Kambing $\mathrm{PE}$ dan kambing AN dapat dipelihara selama $>5$ tahun, kambing PE dan AN dapat berproduksi susu dan daging serta dapat beranak 2 kali dalam 1.5 tahun, dan secara ekonomi usaha kambing layak diusahakan.
\end{abstract}

Kata kunci : pengelolaan sumber daya genetik kambing, nilai ekonomi

\section{PENDAHULUAN}

Indonesaia memiliki potensi ketersediaan sumberdaya alam yang sangat berlimpah dan perlu diberdayakan, sehingga menghasilkan produk-produk yang dapat memberikan manfaat bagi kepentingan bersama (Rusdiana dan Aries 2017). Menurut Arvianti et al., 2019), model pertanian di Indonesia adalah model pertanian keluarga, secara tidak langsung diwariskan turun temurun serta dapat menjaga keberlangsungan kehidupannya dari hasil usaha pertanian dan usaha peternakan. Untuk membuka usaha peternakan tentunya penyediaan lahan yang sangat penting, ketersediaan lahan secara sosial ekonomi, budaya sangat erat kaitannya dengan kehidupan sumberdaya manusia, terutama peternak. Penyediaan pangan dapat dilakukan melalui hasil usaha pertanian maupun usaha peternakan. Selanjutnya dalam kontek pemahaman pengelolaan usaha kambing Peranakan Etwah (PE) dan kambing Anglo Nubian (AN), tentunya menyakut pada pelestarian kambing.

Pengelolaan sumber daya genetik kambing Peranakan Etawah dan kambig Anglo Nubian perlu dilakukan. Kambing PE dan kambing AN, mempunyai potensi biologik dan nilai ekonomi yang cukup baik, sehingga perlu dikembangkan agar populasi kambing meningkat. Menurut Prasetyo dan Nurkholis (2018) kambing etawa sangat berpotensi untuk menghasilkan produksi susu dan daging, sehingga perlu dikembangkan. Kambing selain mempunyai adaptasi untuk berkembang biak yang cukup baik, 
dan dapat membantu perekonomian peternak. Keberadaan kambing PE dan kambing AN dapat dihubungkan dengan pemahaman alam dan kemungkinan ada perubahan di masa yang akan mendatang. Kambing PE dan kambing AN perlu dipertahankan, keberadaanya, selain dapat memenuhi kebutuhan protein juga dapat meningkatkan nilai ekonomi peternak (Rusdiana et al., 2015). Polulasi kambing dapat berkembang atau menurun, tergatung pada kemampuan sumberdaya manusia sebagai pengelola.

Kambing PE, merupakan kambing tipe perah dan produktivitasnya cukup baik dibanding kambing kacang. Melihat keunggulan kambing Etawah tersebut, banyak masyarakat (peternak) yang memeliharanya. Menurut Guntoro et al., (2016), rendahnya skala kepemilikan kambing di peternak, selain rendahnya produksi susu, produktivitas kambing Untuk meningkatkan produksi susu kambing, dapat ditingkatkan dengan memperbaiki mutu genetik, melalui seleksi persilangan dan perbaikan pakan. Peningkatan usaha kambing perah persilangan tidak terlepas dari sambutan positif pasar susu dan daging kambing, walaupun populasinya fluktuatif dari waktu ke waktu (Rusdiana et al., 2015). Kambing Anglo Nubian betina dewasa memiliki tinggi badan sekitar $30 \mathrm{~cm}$ dan berat badan sekitar 60-139 kg/ekor dan kambing jantan Anglo Nubian (AN) memiliki tingi badan sekitar $60-175 \mathrm{~kg} /$ ekor (Zaki, 2010).

Menurut Dhican (2012) kambing Anglo Nubian (AN) sebagai kambing komposit banyak dikembangkan di Inggris, dibentuk melalui persilangan kambing Inggris dan kambing asli Afrikada dan merupakan kambing tipe dwiguna penghasil susu dan daging. Kambing Anglo Nubian (AN) pada musim kawin lebih lama daripada kambing keturunan Swiss, sehingga memungkinkan untuk menghasilkan susu sepanjang tahun (Stemmer at al., 2009). Jenis kambing Anglo Nubian telah banyak digunakan dalam program grading-up beberapa negara tropis untuk meningkatkan produksi susu dan daging. Keturunan kambing lokal, sangat cocok untuk kondisi cuaca panas, saat ini kambing PE dan kambing AN sudah banyak di pelihara di Kandang Percobaan Balitnak Ciawi-Bogor, baik sebagai Plasma Nutfah, pemuliaan dan produksi susu kambing.

Kambing mampu bertahan hidup, karena tingginya daya adaptasi serta karakteristik anatomi fisiologi cukup tinggi (Silanikove et al., 2010). Peran kambing sebagai penghasil susu $60 \%$ lebih banyak dibandingkan sebagai penghasil daging (Malau-Aduli et al., 2001). Setiap jenis kambing memiliki keragaman performa produksi yang berbeda, baik sebagai penghasil susu maupun daging (Zhang et al., 2008). Kambing PE dan kambing AN sudah banyak diusahaan oleh peternak kecil dipedesaan, baik sebagai produksi susu maupun daging. Berdasarkan permasalahan tersebut diatas, usaha kambing PE dan AN dapat dibudidayakan melalui pembibitan dan penggemukan. Menurut Maemunah et al. (2017) untuk mencapai nilai ekonomi peternak lebih optimal, perlu perbaikan manajemen, melalui perbaikan bibit, penyediaan pakan, modal, pasar dan harga. Biasanya semua peternak di pedesaan usaha kambing perah untuk produksi daging. Tujuan penelitian ini adalah untuk mengetahui pengelolaan sumber daya genetik kambing Peranakan Etawah (PE) dan kambing Anglo Nubian (AN) sebagai potensi biologik dan nilai ekonomi, sehingga penelitian ini perlu dilakukan.

\section{MATERI DAN METODE}

Penelitian dilakukan di kandang percobaan Balai Penelitian Ternak Ciawi-Bogor, Jawa Barat 2018. Metoda penelitian menggunakan kambing Peranakan Etawah (PE) sebanyak 35 ekor dan kambing Anglo Nubian (AN) sebanyak 35 ekor yang siap dikawinkan dan siap untuk berproduksi. Kambing betina PE sebanyak 30 ekor dan kambig jantan PE sebanyak 5 ekor. Kambing betina AN sebanyak 30 ekor dan kambing jantan AN sebanyak 5 ekor. Karakterisasi dari ke dua jenis kambing PE dan kambing AN, kemudian di data dan dicatat produksi anak dan nilai ekonomis. Rata-rata kambing PE dan kambing AN betina dan jantan rata-rata umur 1,2-3,6 tahun. Rata-rata kambing betina sudah beranak antara 1-3 kali dan rata-rata bobot badan induk, calon induk dan pejantan antara $20-46 \mathrm{~kg} / \mathrm{ekor}$.

\section{Analisis Data}

Data yang dibutuhkan dalam penelitian ini adalah data primer dan data sekunder. Dimana data primer diperoleh dari hasil kegiatan penelitian di lapang atau di kandang, percobaan Balitnak Ciawi. Data sekunder diperoleh dari jurnal, prosiding, buku yang sudah diterbitkan, informsi dan ide-ide dari pemikiran sendiri sesuai dengan penelitian. Data primer dan data sekunder kemudian dianalisis secara diskriptif kuantitatif dan analisis ekonomi. 
Perkawinan kambing PE dan kambing AN dilakukan secara kelompok, dengan menggunakan 10 kotak kandang. Masing-masing kotak kandang berisi 6 ekor kambing betina dan 1 ekor kambing pejantan, baik kambing PE maupun kambing AN. Sebenarya seekor kambing pejantan PE dan kambing pejantan AN dapat mengawini betina induk dan calon induk antara 5-10 ekor/dalam satu kandang. Menurut Prasetyo dan Nurkholis (2018), melalui sistem perkawinan secara alami pada kambing, dapat meningkatkan performa produksi kambing cukup baik.

Kambing pejantan PE dan kambing pejantan AN dibiarkan dalam kelompok kandang perkawinan selama 2 siklus birahi antara 30-35 hari. Setiap kambing mendapatkan pakan konsentrat sebanyak 0,5-0,7 kg/ekor dan pakan hijauan diberikan sebanyak 3-4 kg/ekor/hari. Pemberian mineral blok disediakan, guna melengkapi kebutuhan akan mineral mikro dan diberi minum ad libitum. Penimbangan bobot induk dilakukan sebulan sekali sampai umur kebuntingan 3 bulan, pada waktu kelahiran dan masa laktasi. Penimbangan anak prasapih dilakukan setiap 2 minggu dan penyapihan dilakukan pada waktu anak berumur sekitar antara 85-90 hari. Kambing PE dan kambing AN dikarakterisasi secara biologi dan morfologi serta potensi sumberdaya genetik secara ex-situ, di ukur sifat-sifat produksinya. Produksi anak dan produktivitas induk, keragaan reproduksi : laju kebuntingan, litter size, bobot lahir, bobot sapih, kemampuan hidup anak, laju pertumbuhan berbagai umur dan jenis kambing. Biaya produksi pada pemeliharaan kambing PE dan kambing AN, meliputi biaya tetap dan biaya tidak tetap. Untuk melihat pengelolaan usaha kambing PE dan kambing AN dihitung berdasarkan kelayakan ekonomi berdasarkan nilai $\mathrm{R} / \mathrm{C}$ ratio.

\section{HASIL DAN PEMBAHASAN}

\section{Populasi Perkembagan Kambing Peranakan Etawah (PE)}

Populasi kambing PE sebanyak 63 ekor, berbagai umur, jantan dan betina. Kambing PE betina dan kambing PE jantan yang masih hidup umur $>7$ tahun disposal atau di keluarkan untuk di jual, dianggap afkir. Produksi anak kambing PE sebanyak 31 ekor, anak kambing betina PE sebanyak 14 ekor dan anak kambing jantan PE sebanyak 17 ekor. Populasi kambing PE di kandang percobaan Balitnak Ciawi-Bogor meningkat menjadi sebanyak 63 ekor atau sebesar 49,96\% /tahun. Populasi kambing PE terlihat pada Tabel 1.

Tabel 1 menujukkan bahwa kematian induk PE sebesar $8 \%$, diakibatkan induk sudah tua. Pejantan yang sudah dianggap afkir, disposal sebesar $0,2 \%$ untuk di jual. kematian anak kambing betina PE dan jantan PE sebesar 15\%$17 \%$, karena pada saat lahir terinjak oleh indukinduk, terperosok dan kematian lainnya.

Tabel 1. Populasi kambing PE selama satu tahun

\begin{tabular}{llll}
\hline Uraian & $\begin{array}{l}\text { Populasi, ekor } \\
(\%)\end{array}$ & $\begin{array}{l}\text { Kematian, } \\
\text { disposal }(\%)\end{array}$ & Keterangan \\
\hline Berina Induk & $28(44,44 \%)$ & $8 \%$ & Sudah afkir \\
Betina anak & $14(22,22 \%)$ & $15 \%$ & Terinjak induk-induk, terprosok atau terjepit \\
Jantan dewasa & $4(6,35 \%)$ & $0 \%$ dan $0,2 \%$ & $\begin{array}{l}\text { Disposal/dijual } \\
\text { Jantan anak }\end{array} 17(26,98 \%)$ \\
\hline
\end{tabular}

\section{Populasi Kambing Anglo Nubian (AN)}

Populasi kambing AN menjadi sebanyak

66 ekor, berbagai umur, jantan dan betina. Kambing AN betina dan kambing AN jantan yang masih hidup dan umur $>7$ tahun disposal atau di keluarkan untuk di jual, dianggap afkir. Kambing AN betina dan jantan AN umur $>7$ tahun disposal atau di keluarkan, dianggap apkir. Produksi anak kambing AN sebanyak 31 ekor, anak kambing betina sebanyak 16 ekor dan anak kambing jantan sebanyak 19 ekor. Populasi kambing AN dikandang percobaan Balitnak Ciawi-Bogor meningkat menjadi sebanyak 66 ekor atau sebesar $53,03 \%$, /tahun. Populasi kambing AN terlihat pada Tabel 2.

Tabel 2 menunjukkan bahwa kematian induk AN sebesar 9\%, diakibatkan induk sudah tua. Kambing pejantan AN yang sudah dianggap afkir, disposal sebesar $0,2 \%$ untuk di jual. Kematian anak kambing betina $\mathrm{AN}$ dan jantan $\mathrm{AN}$ sebesar 18\%-19\%, karena pada saat lahir terinjak oleh induk-induk lain, terperosok dan kematian lainnya. 
Tabel 2. Populasi kambing AN selama satu tahun

\begin{tabular}{llll}
\hline Uraian & Populasi, ekor (\%) & Kematian, disposal (\%) & Keterangan \\
\hline Berina Induk & $27(40,91 \%)$ & $9 \%$ & Sudah afkir \\
Betina anak & $16(24,24 \%)$ & $18 \%$ & Terinjak induk-induk \\
Jantan dewasa & $4(6,06 \%)$ & $0, \%$ dam 0,2 & Disposal/dijual \\
Jantan anak & $19(28,16 \%)$ & $19 \%$ & Terinjak induk-induk \\
\hline
\end{tabular}

\section{Karakteristik Kambing PE dan Kambing AN}

Karakteristik kambing Peranakan Etawah (PE) dan kambing Anglo Nubian (AN) pada bobot lahir anak kambing PE dan AN yang dilahirkan bervariasi tergantung pada jenis kelamin dan tipe kelahirannya. Hasil pengamatan menunjukkan bahwa dengan meningkatnya tipe kelahiran pada kambing PE dan kambing AN, bobot lahir cenderung menurun. Rataan bobot lahir anak kambing jantan PE dan AN tetap lebih tinggi dibandingkan anak kambing betina PE dan $\mathrm{AN}$, di kedua rumpun kambing berbeda. Rataan bobot lahir kambing PE dan kambing AN terlihat pada Tabel 3.

Tabel 3 Rataan bobot lahir per ekor pada kambing PE dan kambing AN

\begin{tabular}{lcccc}
\hline \multicolumn{1}{c}{ Variabel } & $\mathrm{N}$ & $\mathrm{PE}$ & $\mathrm{N}$ & AN \\
\hline Rataan Umum (kg) & 16 & $2,95 \pm 0,82$ & 23 & $2,93 \pm 0,54$ \\
Jenis Kelamin & & & & \\
$\quad$-Betina (kg) & 7 & $2,80 \pm 0,76$ & 18 & $2,84 \pm 0,38$ \\
$\quad$-Jantan (kg) & 9 & $3,07 \pm 0,89$ & 5 & $3,24 \pm 0,92$ \\
Tipe Kelahiran & & & & \\
$\quad$-Tunggal (kg) & 12 & $3,03 \pm 0,88$ & 7 & $3,40 \pm 0,57$ \\
-Kembar 2 (kg) & 4 & $2,70 \pm 0,66$ & 16 & $2,72 \pm 0,39$ \\
\hline
\end{tabular}

Tabel 3 menunjukkan bahwa rataan bobot badan lahir pada kambing PE sebanyak $2,95 \pm 0,82$ $\mathrm{kg}$ dan pada kambing AN sebayak 2,93 $\pm 0,54 \mathrm{~kg}$. Tipe kalahiran tunggal pada kambing PE sebanyak 3,03 $\pm 0,88$ dan AN sebanyak 3,40 \pm 0,57 . Jika dikelompokkan menurut tipe kelahiran anak tunggal jelas lebih tinggi bobot lahirnya dibandingkan dengan anak lahir kembar 2 (dua).

\section{Keragaan Reproduksi Induk Kambing PE dan Kambing AN}

Keragaan reproduksi induk kambing Peranakan Etawah (PE) dan kambing Anglo Nubian (AN), hasil kegiatan plasma nutfah kambing yang dikawinkan sebanyak 30 ekor induk PE, mempunyai rataan bobot kawin sebesar $40,71 \pm 9,94 \mathrm{~kg}$ dan sebanyak 30 ekor induk Anglo Nubian rataan bobot kawin sebanyak 43,10 $\pm 12,13$ kg. Persentase kebuntingan kambing PE dan kambing AN hanya sebesar $50 \%$. Keragaan reproduksi kambing $\mathrm{PE}$ dan kambing AN terlihat pada Tabel 4.

Tabel 4 menunjukkan bahwa, indukinduk yang bunting tidak $100 \%$ beranak, karena beberapa ekor kambing mengalami keguguran pada saat kebuntingan memasuki bulan ke 3 . Kambing Peranakan Etwah (PE) yang beranak tunggal sebesar $78,95 \%$, beranak kembar 2 sebesar $21,05 \%$, dengan rata-rata jumlah anak (litter size) sebesar 1,21. Kambing Anglo Nubian (AN) berbanding terbalik dengan kambing PE yaitu induk kambing AN melahirkan anak tunggal sebesar 21,74\%, induk melahirkan anak kembar 2 sebesar $78,26 \%$, rata- rata jumlah anak sekelahiran (litter size) sebesar 1,70\% dengan kisaran litter size antara 1-2 ekor.

Kambing Anglo Nubian (AN) mempunyai anak kembar lebih banyak (lebih prolifik) dibandingkan kambing Peranakan Etawah (PE). Walaupun kedua rumpun kambing termasuk kambing yang prolifik. Induk-induk yang beranak pada kambing PE mempunyai rata-rata bobot induk setelah beranak sebesar 41,84 $\pm 9,18 \mathrm{~kg}$ dan kambing AN mempunyai rata-rata bobot induk setelah beranak sebesar 42,81 $\pm 9,42 \mathrm{~kg}$. Anak kambing jantan PE sebesar 26,48\% lebih tinggi dari anak kambing betina PE sebesar 22,22\%. Sedangkan pada anak kambing jantan PE sebesar $28,79 \%$, lebih tinggi dari anak kambing betina PE sebesar $24,24 \%$. 
Tabel 4. Keragaan reproduksi induk kambing PE dan induk kambing AN

\begin{tabular}{lcc}
\hline Keragaan reproduksi induk & Kambing PE & Kambing AN \\
\hline Induk kawin (ekor) & 30 & 30 \\
Persentase kebuntingan (\%) & 53,13 & 58,06 \\
Liter size & $1,21(1-2$ ekor) & 1,70 (1-2 ekor) \\
Tingkat kelahairan tunggal (\%) & 78,95 & 21,74 \\
Tingkat kelahiran kembar 2 (\%) & 21,05 & 78,26 \\
Tingkat kelahiran kembar 3 (\%) & - & - \\
Sex ratio (jantan : betina) & $59: 41$ & $14: 86$ \\
Mortalitas prasapih (\%) & 25 & 4,8 \\
Gejala & $1 \mathrm{emah}$ & lemah \\
Bobot induk kawin (kg) & $40,71 \pm 9,94$ & $43,10 \pm 12,13$ \\
Bobot induk beranak (kg) & $41,84 \pm 9,18$ & $42,81 \pm 9,42$ \\
\hline
\end{tabular}

\section{Pengelolaan Usaha Kambing PE dan Kambing AN}

Pada dasarnya pengelolaan usaha kambing baik sebagai pembibitan maupun pembesaran, tentunya membutuhkan biaya yang cukup besar. Biaya produksi yang terbesar biasanya untuk pembelian bibit, pakan, kandang dan tenaga kerja. Kemudian biaya lainnya adalah biaya-biaya yang tidak dapat diprediksi pada pengeluarannya. Untuk usaha kambing di peternak biasanya biaya tenaga kerja diasumsikan kedalam biaya pembelian pakan, karena selama ini peternak tidak pernah menghitung biaya tenaga kerja. Usaha kambing secara komersial, biaya produksi pada pembelian bibit, pakan konsentrat dan sewa kandang. Biaya produksi pembelian pakan pada usaha kambing PE dan kambing AN, dapat diperhitungkan sesuai jumlah kambing yang dipelihara. Nilai ekonomi pada pengelolaan usaha ambing PE dan kambing AN terlihat pada Tabel 5 .

Tabel 5. Pengelolaan usaha kambing PE dan kambing AN

\begin{tabular}{lll}
\hline Uraian & Kambing PE & Kambing AN \\
\hline Biaya biaya produksi dan penyusutan & 33.432 .000 & 36.823 .000 \\
Pedapatan kotor/tahun & 50.730 .000 & 52.950 .000 \\
Pendapatan bersih/tahun & 17.730 .000 & 16.126 .670 \\
R/C & 1,52 & 1,44 \\
\hline
\end{tabular}

Tabel 5 menunjukan bahwa keuntungan bersih hasil penjualan anak kambing jantan $\mathrm{PE}$ dan kambing betina PE sebesar Rp.17.730.000,/tahun dengan nilai $\mathrm{R} / \mathrm{C}$ sebesar 1,52. Keuntungan hasil penjualan anak kambing jantan AN dan anak kambing betina AN sebesar Rp.16.126.670,/tahun dan nilai R/C sebesar 1,44. Hasil Penelitian Rusdiana dan Rijanto (2014) usaha kambing skala 4-6 ekor induk, keuntungan peternak sebesar Rp.1.665.594,-/tahun, R/C sebesar 1,2. Hasil penelitian Prasetyo dan Nurkholis (2018) harga anak kambing atau cempe lepas sapih sebesar Rp.1.1750.000/ekor atau keuntungan peternak sebesar Rp. 9.660.000/tahun. Menurut Maesya dan Rusdiana (2018); Tiven et al., (2019) bahwa kambing mempunya arti tersendiri bagi peternak baik sebagai usaha pokok maupun usaha sampingan. Harga kambing dipengaruhi oleh kondisi tubuh, umur, jenis kambing, jantan dan betina. Kambing dapat melahirkan atau bunting 2 kali dalam waktu 1,5 tahun. Kambing PE dan kambing AN dapat dipelihara selama $>5$ tahun, karena kambing dapat berproduksi anak 2 kali selama 1,5 tahun secara ekonomi usaha kambing layak diusahaan.

\section{KESIMPULAN}

Hasil penelitian disimpulkan, dari berbagai status fisiologi kambing PE dan AN, rata-rata bobot badan kawin kambing betina $\mathrm{PE}$ sebanyak 40,71 $\pm 9,94 \mathrm{~kg}$ dan kambing betina AN

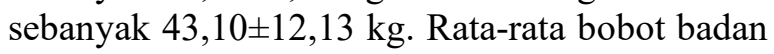
kambing betina PE setelah beranak sebesar $41,84 \pm 9,18 \mathrm{~kg}$ dan rata-rata bobot badan kambing

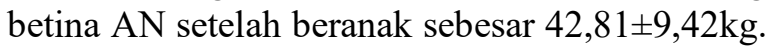
Produksi anak kambing jantan PE sebesar 26,48\% lebih tinggi. Sedangkan anak kambing betina PE sebesar 22,22\% lebih rendah. Anak kambing jantan AN sebesar 28,79\% lebih tinggi. Sedangkan anak kambing betina AN sebesar $24,24 \%$ lebih rendah. 
Keuntungan bersih hasil penjualan anak kambing jantan PE dan betina PE sebesar Rp.17.730.000,/tahun, R/C sebesar 1,52. Keuntunagn bersih hasil penjualan anak kambing jantan $\mathrm{AN}$ dan betina $\mathrm{AN}$ sebesar Rp.16.126.670,-/tahun R/C sebebsar 1,44. Kambing PE dan kambing AN dapat dipelihara selama $>5$ tahun, karena kambing dapat berproduksi susu dan daging, dapat beranak 2 kali dalam 1,5 tahun, pengelolaan usaha kambing PE dan kambing AN secara ekonomi layak diusahaan.

\section{DAFTAR PUSTAKA}

Arvianti, E. Y., Masyur, L. R. Waluyati dan D. H. Darwanto. 2019 Gambaran krisis petani muda di Indonesia. Jurnal Agriekonomika 8

(2): $168-180$

Doi:http://dx.doi.otg/10.21107/agriekono mika.v8i2.5429

Dhican, A. F. 2012. Analisis usaha kambing perah. Stimik Amikom Yohyakarta Research.

http/amikom.tinus.ac.id.php/KIM/ericlevie s (5 September 2015).

Guntoro, B., dan A.N. Rakhman, Y.Y. Suranindyah. 2016. Innovation sdoption of dairy goat farmers in Yogyakarta, Indonesia. International Journal of Environmental \& Agriculture Research (IJOEAR) 2(2): 98-109.

Malau-Aduli, B. S., I.O. Eduvie, C.A.M. Lakpini and A.E.Oelionec. 2001. Effect of supplementation on the milk yield of Red Sokoto does. Proc. of the 26th Annual Conference of Nigerian Society of Animal Production, March 2001 ABU, Zaria, Nigeriapp: 353-355.

Maemunah, S., D.Sufyadi dan I.Hodiyah. 2017. Analisis efisiensi teknis usaha ternak kambing Etawah (Studi Kasus di Kelompok Agribisnis As-Salam Kota Tasikmalaya) Jurnal Pemikiran Masyarakat Ilmu Berwawasan Agribisnis Jurnal Mimbar Agribisnis 3(1):40-52.DOI: http://dx.doi.org/10.25157/ma.v3i1.74

Maesya, A., dan S. Rusdiana. 2018. Prospek Pengembangan Usaha Ternak Kambing dan Memacu Peningkatan Ekonomi Peternak, Jurnal Agriekonomika 7(2):135148 DOI: https://doi.org/10.21107/agriekonomika.v7 i2. 4459
Prasetyo, A. F. dan Nurkholis. 2018. Performa produksi dan potensi pendapatan usaha ternak kambing perah di kabupaten lumajang Jurnal Agribisnis 20(2): 149155.

DOI: https://doi.org/10.31849/agr.v20i2.2064

Rusdiana, S., dan R. Hitasoit. 2014. Peningkatan usaha kambing di kelompok tani sumbersari dalam analisis ekonomi Jurnal Sosial Ekonomi Pertanian 11(2):151-162. DOI: https://doi.org/10.20961/sepa.v11i1.14168

Rusdiana, S., dan A. Maesya. 2017. Pertumbuhan ekonomi dan kebutuhan pangan di Indonesia. Jurnal Sosial Ekonomi dan Kebijakan pertanian, Agriekonomika 6(1):12-26.

Doi:http://dx.doi.otg/10.21107/agriekono mika.v6i1.1795.

Rusdiana, S., L. Praharani dan U. Adiati. 2015. Prospek dan strategi perdagangan ternak kambing dalam merebut peluang pasar. Jurnal Sosial Ekonomi dan Kebijakan pertanian, Agriekonomika 3(2):204-223. DOI: https://doi.org/10.21107/agriekonomika.v3 i2. 455

Silanikove, N., G. Leitner, U. Merin, C.Goernio Prosser. 2010. Recent advances in exploiting goat's milk: Quality, safety and production aspects. Jurnal Small Ruminant Research $\quad 89: 110-124$. Doi.10.1016/j.smallrumes.2009.12.033

Stemmer, A., M. S. Scgultz., C. Gall and A. Zarate. 2009. Develompnet and wordwide, distribution of the anglo nubian goat. Trop. Subtrop. Agroecosyst.11(2):185-188.

Tiven, N.C., H.F. Salamena, D.De Lima, J.M. Tatipikalawan dan I.P. Siwa. 2019. Potensi pengembangan peternakan kambing di Kabupaten Kepulauan Aru Propinsi Maluku. Jurnal Ilmu Ternak, 19(1):10-19. DOI://10.24198/jvt.v19i1.20070

Zaki. 2010. Pengembangan kambing anglo nubian. http://www.goole zaky.co.id.101.2013 (11 Agustus 2017).

Zhang, C.L. Yang and Z. Shen. 2008. Variance components and genetic parameters for weight and size at birth in Boer goat. Livestock Science 115(1):73-79. 